\title{
Mean platelet volume in gestational diabetes mellitus
}

\section{Gestasyonel diabetes mellitusu olan gebelerde ortalama trombosit hacmi}

\author{
Nilgün Güdücü, Güliz Sidar, Uzay Görmüş, Herman İşçi, Alin Başgül Yiğiter, İlkkan Dünder \\ Department of Obstetrics and Gynecology, İstanbul Bilim University Avrupa Hospital, İstanbul, Turkey
}

\begin{abstract}
Objectives: This study aims to compare mean platelet volume of pregnants with gestational diabetes mellitus to a healthy control group and to detect the relationship between mean platelet volume and fasting blood glucose.

Materials and methods: Patients with gestational diabetes mellitus $(n=43)$ were compared to a healthy control group ( $n=43$ ) retrospectively by searching medical records.

Results: Platelet count and mean platelet volume of patients with gestational diabetes mellitus and the control group were not statistically significantly different. There was no statistically significant correlation between mean platelet volume and fasting blood glucose of patients with gestational diabetes mellitus $(r=-0.207, p=0.189)$. Complete blood count results of the two groups were compared, only hemoglobin levels were statistically significantly different.
\end{abstract}

Conclusion: There was no difference in mean platelet volume of patients with gestational diabetes mellitus and controls. There was also no relationship between mean platelet volume and fasting blood glucose of patients with gestational diabetes mellitus.

Keywords: Gestational diabetes mellitus; hemoglobin level; mean platelet volume.

ÖZ

Amaç: Bu çalışmada sağlıklı kontrol grubunu oluşturan gebeler ve gestasyonel diabetes mellitus olanların ortalama trombosit hacimleri karşılaştırıldı ve ortalama trombosit hacmi ile açlık kan şekeri arasındaki ilişki araştırıldı.

Gereç ve yöntemler: Tıbbi kayıtları retrospektif olarak araştırılarak gestasyonel diabetes mellitusu olan hastalar ( $\mathrm{n}=43$ ), sağlıklı gebe kontrol grubu $(n=43)$ ile karşılaştırıldı.

Bulgular: Kontrol grubunu oluşturan sağlıklı gebelerde ve gestasyonel diabetes mellitusu olanlarda yapılan trombosit sayımı ve ortalama trombosit hacmi arasında istatistiksel olarak anlamlı fark bulunmadı. Gestasyonel diabetes mellitusu olan hastaların açlık kan şekeri ve ortalama trombosit hacmi arasında da istatistiksel olarak anlamlı ilişki bulunmadı $(r=-0,207, p=0.189)$. Her iki grubun tüm kan sayımı parametreleri karşılaştırıldığında, sadece hemoglobin seviyelerinde istatistiksel olarak anlamlı farklılık bulundu.

Sonuç: Kontrol grubunu oluşturan sağlıklı gebeler ve gestasyonel diabetes mellitus olan hastalardaki ortalama trombosit hacmi arasında anlamlı bir fark yoktur. Ayrıca gestasyonel diabetes mellitus olan hastaların açlık kan şekerleri ile ortalama trombosit hacmi arasında bir ilişki bulunamamıştır. Anahtar sözcükler: Gestasyonel diabetes mellitus; hemoglobin düzeyi; ortalama trombosit hacmi.

Gestational diabetes mellitus (GDM), defined as glucose intolerance diagnosed for the first time during pregnancy, is the most common metabolic complication of pregnancy. Gestational diabetes mellitus is associated with an increased risk of maternal and fetal complications during pregnancy and in the immediate postpartum period. ${ }^{[1]}$ These patients also have a higher risk of developing type 2 diabetes mellitus (DM) in the future. Gestational diabetes mellitus was presented as a significant antenatal risk factor for thromboembolism in a large epidemiological study. ${ }^{[2]}$

Hyperglycemia and insulin increase platelet activation $^{[3]}$ and activated platelets have a higher thrombogenic potential ${ }^{[3]}$ Platelet activity and 
aggregation potential, can be easily estimated by measuring mean platelet volume (MPV) as part of complete blood count $(\mathrm{CBC}){ }^{[4]}$ Large platelets are more active than smaller platelets and produce more prothrombotic factors and this indicates that changes in the platelet count and MPV reflect the state of thrombogenesis. ${ }^{[4]}$ Mean platelet volume of patients with type $2 \mathrm{DM}$ are higher than controls ${ }^{[5,6]}$ and patients with GDM also have higher MPV,${ }^{[7,8]}$ yet other studies present contradictory results. ${ }^{[9]}$

In this study we measured MPV in patients with GDM and compared it to nondiabetics and tried to determine the correlation of MPV with postprandial plasma glucose in patients diagnosed with GDM.

\section{MATERIALS AND METHODS}

This is a retrospective study carried out by searching charts of patients between January 2009 and June 2013. We compared the data of pregnants with GDM to a healthy control group. Patients with any other systemic disease, twin pregnancies, pregnants with DM diagnosed before pregnancy or in the first trimester, pregnancies with any known fetal chromosomal and congenital abnormalities and those using antifibrinolytic or anticoagulant drugs were excluded. We did not exclude pregnants with hypothyroidism. We screened pregnants without a previous history of DM between 24 and 28 weeks of pregnancy with 50 gram one hour glucose challenge test, those with a value $\geq 140 \mathrm{mg} / \mathrm{dL}$ were advised to undergo a 100 gram, three hour oral glucose tolerance test (OGTT). Pregnants with two or more positive values were diagnosed as GDM (positive values at fasting, 1 hour, 2 hour and 3 hour were accepted as $\geq 95,180,155$ and 140 respectively).[10] Pregnants with a positive
50 gram challenge test but a negative 100 gram OGTT were excluded from both of the groups. Pregnants with a 50 gram glucose challenge test result $\geq 200 \mathrm{mg} / \mathrm{dL}$ were also diagnosed as GDM without a further diagnostic test. Fifty gram glucose tolerance test was done without a prerequisites of fasting and patients gave blood for CBC (Roche Sysmex 2000i) at the same time and 100 gram OGTT was done after three days of carbohydrate rich meals, while fasting. The study protocol was in confirmation with the ethical guidelines of the Declaration of Helsinki.

Statistical analyses were performed using the Number Cruncher Statistical System (NCSS) 2007 \& Power Analysis and Sample Size (PASS) 2008 Statistical Software (Utah, USA). Data showing normal distribution of parameters were compared with Student's t-test, relation of MPV with other CBC parameters was compared with Pearson's correlation analysis.

\section{RESULTS}

The $\mathrm{CBC}$ results of the two groups was compared in Table 1, only hemoglobin levels were statistically significantly differed, patients with GDM had lower hemoglobin levels. There was no statistically significant correlation between MPV and fasting blood glucose of patients with GDM $(r=-0.207$, $\mathrm{p}=0.189$ ).

\section{DISCUSSION}

In this study we did not detect a difference in MPV of pregnants with and without GDM. There was also no correlation between MPV and fasting blood glucose levels of pregnants with GDM. Previously two studies detected higher MPV in patients with GDM when compared to the control group, ${ }^{[7,8]}$ but they did not check the presence of correlation

Table 1. Comparison of the complete blood counts of the groups

\begin{tabular}{|c|c|c|c|c|c|}
\hline & \multicolumn{2}{|c|}{ Control group $(n=43)$} & \multicolumn{2}{|c|}{ Gestational diabetes group $(n=43)$} & \multirow[b]{2}{*}{$p$} \\
\hline & Mean \pm SD & Range & Mean \pm SD & Range & \\
\hline Age (years) & $30.02 \pm 4.26$ & $21-39$ & $32.21 \pm 4.32$ & $25-43$ & $0.020^{*}$ \\
\hline Hemoglobin $(\mathrm{g} / \mathrm{dL})$ & $11.88 \pm 0.81$ & $10.5-13.7$ & $11.44 \pm 0.98$ & $9.7-13.9$ & $0.028 *$ \\
\hline Hematocrite & $34.58 \pm 2.16$ & $31.3-40.5$ & $33.94 \pm 3.92$ & $27.1-52.5$ & 0.355 \\
\hline White blood cell count $\left(x 10^{3} / \mathrm{mL}\right)$ & $9952.40 \pm 2571.26$ & $1703-14.400$ & $10466.40 \pm 2924.67$ & $1118-19160$ & 0.389 \\
\hline Platelet count $\left(\times 10^{3} / \mathrm{mL}\right)$ & $232813.95 \pm 52607.83$ & $153000-387000$ & $211116.28 \pm 67218.98$ & $96000-488000$ & 0.099 \\
\hline Mean platelet volume (fl) & $10.21 \pm 0.90$ & $8.7-12.5$ & $10.33 \pm 1.03$ & 8.5-12.7 & 0.573 \\
\hline Fasting blood glucose (mg/dL) & $90.65 \pm 6.63$ & $65-115$ & $96.81 \pm 14.03$ & $79-167$ & $0.020^{*}$ \\
\hline
\end{tabular}

SD: Standard deviation; Student-t test; ${ }^{*} \mathrm{p}<0.05$. 
between MPV and glucose levels. Other studies in patients with type $2 \mathrm{DM}$ detected statistically significantly higher MPV in diabetic group when compared to nondiabetic subjects. ${ }^{[5,6]}$ Platelet activity was detected as statistically significantly higher in patients with higher $\mathrm{HbA1c}$ levels ${ }^{[6]}$ and MPV was significantly decreased in patients with poor glycemic control after achieving improved glycemic control. ${ }^{[6]}$ Metformin, which has been shown to exhibit antiatherogenic effect by decreasing cholesterol levels, inflammatory markers and vascular adhesion molecules, decreased MPV values. ${ }^{[1]}$ Other studies showed higher MPV among type 2 DM patients who had microvascular complications (retinopathy or microalbuminuria). ${ }^{[5]}$

The large platelets contain more dense granules, are more potent than the smaller platelets, and are hence more thrombogenic. Both the size and number of granules in platelets in circulation are under independent hormonal control and do not change during the life span of the platelet. Platelet activation triggers thrombus formation and leads to microcapillary embolization with the release of constrictive, oxidative, and mitogenic substances such as platelet-derived growth factor and vascular endothelial growth factor. ${ }^{[3]}$ Hyperglycemia was suggested to increase platelet reactivity by inducing nonenzymatic glycation of proteins on the surface of the platelet and insulin was shown to regulate platelet activity via functional insulin receptor (IR) found on human platelets. ${ }^{[3]}$ The abnormal regulatory signaling pathways of platelets in DM result in increased activation and aggregation in response to a given stimulus. ${ }^{[3]}$ In a study with streptozotocin-induced diabetic rats, it was reported that there was an increase of thromboxane B2 production and platelet activation far before than endothelial damage. ${ }^{[12]}$ Although this study suggested a platelet dysfunction that begun at the early stages of diabetes even before occurrence of vascular pathology, we reason a cautious approach to this idea in patients with GDM. Three studies reported findings about MPV and GDM, two of them proposed higher MPV in GDM and the other one opposed this. ${ }^{[7-9]}$ In our study and study of Bozkurt et al. ${ }^{[8]}$ patients with GDM were older than the controls, but the main difference was the gestational age at which MPV was measured. Blood for measuring MPV was obtained at a later gestational age than ours in that study, and the elapsed time might have created differences that could change MPV. The other study gives limited knowledge about criteria used in the diagnosis of GDM and this overshades the results. ${ }^{[7]}$ In preeclamptic pregnants MPV increased gradually until term when compared to normal pregnants, ${ }^{[13]}$ such a longitudinal study may provide better foresight. The increased MPV as the cause or the end result of vascular complications needs to be further explored.

In conclusion there was no difference between MPV of patients with and without GDM when checked at the gestational week when GDM was diagnosed, but longitudinal studies might change the results and might provide a diagnostic marker that could be used to predict disease morbidity and mortality.

\section{Declaration of conflicting interests}

The authors declared no conflicts of interest with respect to the authorship and/or publication of this article.

\section{Funding}

The authors received no financial support for the research and/or authorship of this article.

\section{REFERENCES}

1. Reece EA. The fetal and maternal consequences of gestational diabetes mellitus. J Matern Fetal Neonatal Med 2010;23:199-203.

2. Jacobsen AF, Skjeldestad FE, Sandset PM. Incidence and risk patterns of venous thromboembolism in pregnancy and puerperium--a register-based case-control study. Am J Obstet Gynecol 2008;198:233.e1-7.

3. Kakouros N, Rade JJ, Kourliouros A, Resar JR. Platelet function in patients with diabetes mellitus: from a theoretical to a practical perspective. Int $\mathrm{J}$ Endocrinol 2011;2011:742719.

4. Bancroft AJ, Abel EW, Mclaren M, Belch JJ. Mean platelet volume is a useful parameter: a reproducible routine method using a modified Coulter thrombocytometer. Platelets 2000;11:379-87.

5. Papanas N, Symeonidis G, Maltezos E, Mavridis G, Karavageli E, Vosnakidis T, et al. Mean platelet volume in patients with type 2 diabetes mellitus. Platelets 2004;15:475-8.

6. Demirtunc R, Duman D, Basar M, Bilgi M, Teomete $\mathrm{M}$, Garip T. The relationship between glycemic control and platelet activity in type 2 diabetes mellitus. J Diabetes Complications 2009;23:89-94.

7. Erikçi AA, Muhçu M, Dündar O, Oztürk A. Could mean platelet volume be a predictive marker for gestational diabetes mellitus? Hematology 2008;13:46-8. 
8. Bozkurt N, Yilmaz E, Biri A, Taner Z, Himmetoğlu O. The mean platelet volume in gestational diabetes. $\mathrm{J}$ Thromb Thrombolysis 2006;22:51-4.

9. Yin SM, Li YQ, Xie SF, Ma LP, Wu YD, Nie DN, et al. Study on the variation of platelet function in pregnancy induced hypertension and gestational diabetes mellitus. Zhonghua $\mathrm{Fu}$ Chan $\mathrm{Ke} \mathrm{Za} Z \mathrm{Zhi}$ 2005;40:25-8. [Abstract]

10. Carpenter MW, Coustan DR. Criteria for screening tests for gestational diabetes. Am J Obstet Gynecol 1982;144:768-73.
11. Dolasık I, Sener SY, Celebı K, Aydın ZM, Korkmaz U, Canturk Z. The effect of metformin on mean platelet volume in diabetic patients. Platelets 2013;24:118-21.

12. Alessandrini P, McRae J, Feman S, FitzGerald GA. Thromboxane biosynthesis and platelet function in type I diabetes mellitus. N Engl J Med 1988;319:208-12.

13. Dundar O, Yoruk P, Tutuncu L, Erikci AA, Muhcu $\mathrm{M}$, Ergur AR, et al. Longitudinal study of platelet size changes in gestation and predictive power of elevated MPV in development of pre-eclampsia. Prenat Diagn 2008;28:1052-6. 